\title{
Untrained Foreign English Educators in Japan: A Discourse on Government Education Initiative and Perceptions from Japanese Teacher's on Efficacy in the Classroom
}

\author{
Gregory Paul Chindemi \\ Chugoku Gakuen University, Okayama, Japan \\ https://orcid.org/0000-0003-0585-5465
}

\begin{abstract}
Social scientists, teacher leaders, and academics, both Japanese and non-Japanese, have attempted to examine the phenomenon of unlicensed foreigners in the Japanese classroom environment. In an attempt to open a discourse on the intentions and subsequent failures of the JET programme, and to identify specific perceptions of Japanese teachers in relation to JET, a historical analysis of the JET programme coupled with a Likert Scale survey was utilized. In this ordinal scale survey, the opinions of both experienced Japanese teachers and inexperienced Japanese teachers on the challenges of working in conjunction with untrained foreign instructors during their career, were used to gauge teacher's attitudes and opinions. Results would suggest that teacher's with longer time in the field of education have stronger opinions towards untrained foreign educators in the classroom, while less experienced teachers are more apt to working with untrained foreign educators without expressing dissatisfaction.
\end{abstract}

Keywords: government education initiative; English education in Japan; ALT; education training; teacher experience

\section{Introduction}

When considering the scope and degree of difficulty in implementing nationwide education initiatives, few have been as grandiose as what the country of Japan proposed in the fall of 1987. While some researchers (Maeda, 2013; Ishi, 2009; Brown, 2008; Borg,2018) seem to trace a path of origin to two prominent English language programs, most notably, the 1977 Monbusho English Fellow Project (Abb. MEF), and the 1978 British English Teachers Scheme (Abb. BETS), a delve into the tense political climate of the world in the mid-late 1980's reveals a more complex narrative. 
The longest running language teaching exchange program in the world known as the JET Programme (Japanese Exchange Teaching Programme), at its inception in 1987, included 848 participants from 4 participating countries (the United States, the United Kingdom, Australia, and New Zealand) (JET programme participant information, 2019). Bilked as a Japanese tax funded language and cultural exchange program, Ohtani (2010) explained that the poor eligibility criteria for entry into the programme was intentional. Applicants to the program required no background in education or teaching, alternatively applicants only needed to possess a four-year college degree in any field, a native skill in the English language, and an eagerness to live in Japan. The title Assistant language teacher (ALT) was adopted in 1988, shortly after the program began instead of teacher in order to create a "non-threatening hierarchy" in the Japanese workplace (p.44). While overwhelmingly comprised of untrained, newly college graduated native English speakers, who were often unfamiliar with the essential skill set to effectively navigate a classroom, the JET Programme has flourished for nearly 33 years. According to the 2020 public information release from the Japanese Ministry of Education and the Ministry of Internal Affairs and Communication (Abb. MIC) over 5,761 foreigners currently are employed through JET by the Japanese government and currently living in Japan (MIC, 2020).

Researchers on government policy and cultural relations, Metzger (2012) and McConnell (2000) present convincing cases, suggesting that this program, originally created as a form public diplomacy once held substantial merit. However, Metzger (2012) also points out that, "the evolution of the program's mission over time is responsible for the dearth of studies examining components other than educational value"(p.11). While she acknowledges that the core goals of programme were originally rooted in cultural exchange, Ohtani (2010) suggests the quality of the program in terms of an educational initiative must be assessed by qualitative means, and result driven data, in order to attempt to form an opinion on whether or not the JET Programme can be thought of as beneficial to Japanese communities or schools.

The intentions in this research are manifold: to address the historical and circumstantial political implications for the JET Programme, to highlight what can be construed as apparent failures to the inferred educational aims of the program, to evaluate strong criticisms of the program from Japanese journalists and researchers, to unpack the viewpoints of prominent teacher leaders on what constitutes a "quality teacher", and to present qualitative data from Japanese teachers concerning the challenges that encompass working in conjunction with an untrained foreign teacher.

\subsection{The "Ron-Yasu Relationship" (1982-1987)}

While the period from 1945-1952-a regime of the indirect American military rule in Japan-was considered by historians to be an occupation that was more "reformist than revolutionary", aspects of it is played vital role in the groundwork for future educational initiatives (Mason \& Caiger, 2001, p.355). The architecture of Japanese society including: police forces, education, labor 
relations, large scale business, and both urban and rural landholdings, were fundamentally altered to resemble the democratic standards reminiscent in the United States. However, more pertinent in terms of educational reform, American derived syllabi for core subjects being taught at all levels of education, were inserted into the Japanese classroom. Starting in 1947, and for the first time in the history of Japanese education, social studies courses, primarily comprised of American, and more specifically, democratic perspectives in relation to the world, became compulsory for all Japanese junior high and high schools.

As the 1980's approached, America was in deep in the throes of a recession caused by disinflationary monetary policies and oil price increase from the Iranian revolution of 1979. Simultaneously, Japan was leading the world in six major industries; textiles, iron \& steel, home appliances, automobiles, telecommunications, and semi-conductor technology (Shapiro, 1983, pp.33-36). American bases remained stations for logistic operations through the 1960's and during the Vietnam War in 1970. America, and countries in Europe remained entangled in world conflict, while Japan was able to focus solely on its own economic markets, under the backdrop of the impending cold war with the Soviet Union.

Under Prime minister Yasuhiro Nakasone, Japan as an economic leader, had come to hold prestige amongst the United Nations, the World Bank, and the exclusive organization for cooperation and development. Yet, it wouldn't achieve this until, through coercion and persistence, the Japanese government yielded to the United States and opened their markets to American goods. President Reagan, in an effort to thwart the protectionist economic policies of the 1970 `s, sought to change the dynamic between both Japan and the United States. Japan had previously restricting imports, while incentivizing their own exports, and Reagan applied constant pressure to Japan to open trade (Shapiro, 1983, pp.33-36).

Remarking on Japanese Prime minster Nakasone, Mason \& Caiger (2001) assert:

"Nakasone presided with distinction, and in a general atmosphere of calm and self-confidence, over a party and nation traversing what may come to be seen as the peaks of a particular and important stage of their development" (p.366).

Two years prior to the creation of the JET Programme, the United States had imposed an unreasonable 100\% import tax on all Japanese computers, TV and technology, in an aggressive strategy to force Japan into signing agreements to share semiconductor technology and open the border to American imports. The Ron-Yasu relationship was a benchmark for Japan in that it significantly improved Japan's relationship with all western powers-and in consideration of the modern western world's adoption of Japanese cars, goods, and technology- it has been economically speaking-mutually beneficial. Nonetheless, the imposed trade agreement, signed in 1986, would come to include an unexpected omiyage (Japanese gift) from the Japanese government offered at the Nakasone-Reagan trade agreement summit in 1986. 
As noted by McConnel (1996), it was the head of the ministry of foreign affairs, Ikuyo Sato, who presented the idea at the Nakasone-Reagan trade agreement summit as one alternative method to use surplus yen from Japan's overflowing annual trade surplus. Despite unanimous opposition from the members of the Ministry of Education, the 300-million-dollar JET Programme was emphatically pushed through by the divisions of government that would come to oversee the programme to this day- Ministry of Home Affairs and the Ministry of Foreign Affairs. The programme was promoted on two premises; that $90 \%$ of the money spent on funding the JET Programme would 'stay in Japan', assuming that foreigners would spend the lucrative salaries that they earned within Japan, and that the programme would act as a 'grassroots cultural exchange', putting local Japanese communities in direct contact with foreigners living amongst them (McConnel, 1996, pp.440-448).

Past researchers on the JET Programme have provided comprehensive material on the complex governance and the justifications of its present-day continuation (Brown, 2008; see also Borg, 2018; Ishi, 2009; Maeda, 2013; Metzger, 2012; McConnell, 1996; Reed, 2015). However, in terms of addressing the goals of the JET Programme and how those goals have been met over the years, Borg`s (2018) macro perspective seems to articulate most clearly:

Suffice it to say, there are myriad vested interests across Japan that have benefited (and continue to benefit) from JET's existence. In other words, it is inevitable that different individuals and groups will perceive the goals of the programme according to their own interests (p. 199).

In this vein, he emphasizes that the three ministries that currently oversee the JET Programme; the Ministry of Home Affairs, the Ministry of Education, and the Ministry of Foreign Affairs retain a fundamental and self-seeking 'cui bono' component ('who benefits') disposition in regard to the distribution of the financial resources involved with JET. Along with these financial interests, each department has differing ambitions for the program; to allow an influx of foreigners into Japan from year to year, to promote an mutual understanding of culture and society amongst the youth, and the goal that I would like to most emphasize in this research, "a representative of the third agency, the Ministry of Education, Science, and Culture, improving Japanese students' and teachers' "communicative competence in English" (McConnel,1996, as cited in Metzger, 2012, p.448).

Reed (2015) in a comparison of an interview with a Jet participant from 1988, and a respondent from 25 years later, draws attention to the unchanging ambiguity that some foreigners possess in relation to their responsibility in the classroom. The 1988 participant was quoted saying, "I do not know what we are here for", while a respondent who was interviewed 25 years later, in 2014 replied, "I feel like my job is akin to an English mascot, and there is little value in what I do"(p.1). In trying to understand the lack of clarity some foreign assistant instructors might have towards the education system, one must understand the low standards of eligibility for the program, and the lack of systematic training to prepare each instructor for their role in the classroom environment. To put complete blame on the JET participant for the lack of efficacy in the classroom, is 
to ignore the inconsistencies within the organizations that facilitate their employment.

According to an AJET (a volunteer JET council comprised of JETs) study conducted among 450 participants, $88.9 \%$ of them felt unqualified or unprepared to work towards the goals that were created by the Ministry of Education (Abb. MEXT) (Ohtani, 2010). In her commentary, Ohtani (2010) articulates, "ALTs have insufficient education \& pedagogic background, and they are thrown into the Japanese education system without adequate training and preparation"(p.40). In the words of a former JET recruiter and consular official, "ALTs are not regarded as pedagogues, but as 'cheerleaders for the English language' "(Borg, 2018, p.260).

The lack of credentials, and subsequently, background in education of JET participants, can be clearly exemplified in publicly available records obtained from the The Council of Local Authorities for International Relations (abb. CLAIR) website. In a representative sample of 392 JETs, only 5\% of applicants had an education background, and a mere $1 \%$ of the applicants had an academic specialization in what is considered by countries as a pre-requisite qualification to teaching the English language effectively in a non-English speaking country TEFL or TESL training. In fact, TEFL (teaching English as a foreign language) and TESL (teaching English as a second language) certifications are mandated requirements to teach English in Korea, China, Thailand, or Vietnam. A minimum 120-hour course in TEFL/TESOL is required to obtain a work visa, and to legally teach in a classroom as an ALT (Debella, 2018; Kenszei, 2018; Liang, 2019; Teachers Council of Thailand, 2019).

Moreover, the representative sample reveals that $42 \%$ of the applicants have no work experience prior to be given the responsibility of assistant language teacher in the Japanese classroom. Education researcher Maeda (2013) expresses her discontent with the contradictions she finds between the Ministry of Education's goals for the classroom, and the presumption that an untrained educator would be of benefit to Japanese students. She expresses that:

"The people who benefit most from the JET Programme is neither Japanese students, Japanese English teachers, nor Japanese communities; rather the JET teachers who receive a high salary in spite of their amateur status benefit the most, and enjoy their stay in Japan with full financial support" (p.227).

The tone of this criticism, and similar dissatisfaction are echoed repeatedly throughout Japanese academic publications. If the elephant in the room is can be represented by the untrained educator, it would seem that each year the JET program continues, Japanese classrooms are bombarded by a stampede. To what level of detriment, or benefit, this program has had for Japan in the last 30 years? In the next section, I will explore criticism of the program from articles written by Japanese critics, and address the concept of nativism in the English industry of Japan. 


\subsection{Criticism from the Past}

In an unprecedented Japanese election for Prime minister, Yukio Hatoyama and the Democratic Party of Japan, ousted the 5-decade long rule of the Liberal Democratic Party. Mr. Hatoyama, while only in power from 2009-2010, sought to re-examine the relationship that Japan had previously held with the United States since the 1960's. He favored removing American bases from Okinawa, and rejected the LDP's long standing exclusivity and reliance on the United States (Hatoyama, 2009). His reformative policy planning, and heavy hand in the reorganization of the ministry lead government, seemed to simultaneously couple with fervent objections towards the state of the JET program and ALT participants in Japan. As rumors that the program was being cancelled due to financial budget cuts began to appear on job classified websites aimed at foreigners, academics and figures in the government began to lobby aggressively for its immediate disbandment (The End of the JET Program, 2010).

In a written account taken from a local government research conference titled "JET Program wa Haishi Subeki" [The Jet program should be abolished] Ishi (2009) expresses his thoughts on the budget of the "English Note" program being cut at public elementary schools in Japan. He debated that if English programs that originated in Japan, such as the "English Note" textbook series and curriculum, should be cut from local governments budgets, why should the JET program be allowed to remain a financial burden on the taxpayers of each prefecture when it provides no evidence of having a significant impact on student learning (pp. 2-9).

He points out to the government research committee that hiring one unqualified teacher from overseas costs Japanese taxpayers the equivalent of 600-900 man $(60,000-90,000$ US dollars) for their entire 2-3-year tenure stay in Japan. This includes a free round-trip plane ticket, apartment rental assistance, minimal training, and resources from the prefectural board of education to facilitate the needs of each participant. In 2009, 4,436 participants from JET were invited to Japan, and the average cost was 26,616 million yen (266 million 160,000 thousand US dollars). This enormous fee was primarily paid by tax revenue from Japanese citizens, who were under the false impression that the JET program is a useful education initiative with noteworthy benefits for their children. In comparison, the average salary of a trained and licensed 1st year Japanese public servant averaged between 250-300 man per year (25 to 30 thousand USD) depending upon prior experience. Ishi (2009) poses the question, "how did a volunteerbased program that was originally designed for cross cultural understanding evolve into a lucrative job position?" (p. 7).

In a recorded interview with a 32-year-old certified New Zealand teacher, who was currently working for the JET program, Ishi (2009) acquired an insider's point of view as to how some foreigners may view the MEXT education initiative. "From the opinion of the JET, the job is fun, the pay is high, so many foreigners are not thinking of teaching, the impact on students, or cross-cultural communication, but simple the money" (Ishi, 2009, p.8). 
While this does not represent the opinion of all JET participants, recent YouTube videos uploaded by JET participants seem to support this narrative. Out of a series of videos using the search tag, the JET Program in the YouTube search bar, a common theme was prominent. In each video the high salary was highlighted, and the fun factor of living in Japan was the main focus. Little was mentioned about the implications of teaching, and only one video creator stated the benefit of having a qualification, which was quickly retracted in the confirmation, that the JET Program does not require actually qualification to be employed (Allison in Tokyo, 2020, Cara adventures, 2017, Sarah loves Japan, 2019).

In addition to Ishi (2009), other researchers during this period of time also expressed discontent at the continuation of the program (Tenma, 2008; Maeda, 2013; Ohtani, 2010; Canales, 2015). Mariko (2008) in an article titled Dare mo shiranai ALT [The ALT that nobody knows] lists her first-hand observation of the program's participants, and the results from an online survey she had conducted in Osaka about the usefulness of the JET Program. She claimed that although many Japanese English teachers (Abb. JTE) see major issues with the JET participants, they ignore the problems or deny that they exist as to not cause trouble in their workplace. She angrily states that even though Osaka government officials and the Tokyo administration under Shintaro Ishihara have called the JET Program an "Amakudari scheme" [a system where high-ranking government officials take a lucrative paying job in the private sector before retirement]. It is worth noting that her online survey concerning the JET Program, which expressed the opinions of 1,000s of Japanese citizens, was erased by the JET council and the ministries which govern the JET program almost immediately after being made public on her website (Tenma, 2008, pp.12). The readers of her article are left with a resonating question that she revisits on several occasions: just because someone speaks the English language at a native level, does that mean they are also able to effectively teach the English language? I would like to briefly consider this question in relation to the concept of nativism, and contemporary statistics connected to English education in Japan.

\subsection{Japan's Proclivity for Native Speakers}

A Native speaker is defined as someone who speaks English as their first language, and is also a citizen of one of these seven countries: Australia, the UK, USA, Ireland, Canada, South Africa, and New Zealand. Although Singaporeans, Filipinos, Indians, Malaysians, and citizens of Caribbean Islands may be extremely proficient in the English language. In fact, the English Proficiency Index, that rates the English of 88 countries and regions, has reported that Malaysians and Singaporeans are the best English speakers in Asia (Ang, 2021). Native speakerism is explained as "prejudice, stereotyping, and or discrimination typically by or against foreign language teachers, on the basis of either being or not being perceived and categorized as a native speaker of a particular language"(Rivers \& Ross, 2013, p. 62). Countries that fall under the label of non-native English speaker can often find it incredibly difficult to find an English teaching position in Japan, and are often rejected during the interview process in favor of those who fit certain "idealized attributes" created 
by "socio-historical constructs of racial difference and hierarchy" (Rivers \& Ross, 2013, p. 326).

While JET participants are overwhelmingly American, as exemplified in sample graph above, in a positive display of inclusion, JET seems to provide a fair opportunity for participants from over 57 countries to become an ALT and work in Japan (CLAIR, 2015). However, this is contrary to other sectors of Japanese education, particularly in tertiary career tracks, which tend to give preference to non-Japanese candidates "native-ness as the qualification to teach the English language"(Morikawa, 2019, p.27).

Retired professor, Dr. Luiz Canales, who is a 39 year university level teaching veteran in the Japanese education system, explains that "most of the foreign professors invited to teach in foreign language universities, aren't language/literature professors, but native speakers with a university degree in some other field, who were lucky enough to get a teaching job in Japan"(Canales, 2015 , p. 347). He recalled a "strong argument" he had with a colleague concerning un-qualified teachers and native-speakerism:

"Almost any foreigner can easily teach college in Japan. Peter, an unemployed New York lawyer (a fictitious example, but reality in Japan) come to this country. He is a certified lawyer but has no credentials to be an English professor. Now, because he is an English native speaker, he finds his way to the classroom of a Japanese university............there are probably hundreds and hundreds of similar examples......I've had colleagues teaching in Japanese universities, who, back home worked in fields that had nothing to do with teaching....it fools the students who believe they are being taught by professionals" (p. 305).

In a study conducted on English program reform in Japanese universities, Morikawa (2019) compares two types of contrasting global studies programs; One is the "English as a Lingua Franca" (ELF) program at Tamagawa University, and the other is what he claims is a "recurrent pattern" at the universities he has selected to research in Japan. For the demonstration of this pattern he uses visual and textual elements from 7 varied universities in different prefectures of Japan, in addition to his main focus, the Tokyo International University-Global Teaching Institute (GTI) (p.27).

Morikawa (2019) finds that at Tamagawa University (ELF) the concept of learning English is viewed as "a variety of Englishes that are used for communication purposes by people whose first language is not English" (p.31). The staff is represented by people from all over the world: the U.S., the UK, Australia, Italy, Germany, Turkey, Bulgaria, Brazil, Canada, China, Thailand, the Philippines, and Singapore. Additionally, each teacher has received adequate TESOL training, and are experienced educators. As 80\% of the world's English speakers are, in fact, non-native English speakers, he states that this particular university takes a realistic approach towards "true globalization", and claims that it is "inefficient to aim to master the English that is only spoken by $20 \%$ of the entire English speaking population within a certain period of time" (p. 31). Similarly, Norimitsu (1997) adds that native speakers of English seem to have 
"little benefit in the classroom", claiming that Japanese students are forced to pay attention to native speaker's English, and are not given the opportunity to hear non-native's speaking English from other countries (p. 512). He concludes that Japanese students only learning pitch perfect native English can almost be a detriment to their image, and in effect, their expectations of the English language when they visit other countries. Yazawa (2017) reinforces this by stating "while the rest of the world, has long discovered that British or North American pronunciation as a gold standard is a myth, Japanese employers still value it" (p.67).

It is evident that each researcher referenced above, including Dr. Canales, present both strong opinions and in some instances, convincing evidence for native-speakerism in Japan. This being said, it would be remiss to assume that a valid contrary point of view cannot be made in light of the obvious quantitative research limitations. According to Statista (2021) Japan has 4,874 high schools, 10,142 lower secondary schools, 95 public universities, 597 private universities, 86 national universities, and 3,115 specialized colleges. This burden, makes effective data collection difficult, and finding current data on the certifications and nationalities of all non-Japanese educators in Japan a nearly impossible task.

\subsection{Current Statistical Data Verses the Intended Outcomes of the JET Programme}

As Metraux (2001) stated almost 20 years ago, "while JET has brought meaningful contact between thousands of foreigners \& millions of Japanese people, who might not have ever spoken to a foreigner -- the governments hope that JET would improve English in Japan has not been realized"(p. 96). This researcher's assessment, although made two decades ago, is worth revisiting in the present day. Has JET accomplished its goals of grassroots global exchange at the local level, and has this increased the Japanese willingness to engage with foreign people or consider travelling abroad? Has the level of English increased in Japan since the JET Programme began in 1987, slowly growing to employ more than 5,000 foreigners as instructors in Japanese school systems? According to a few recent analytics in relation to the state of English and interest in cultural exchange, the definitive answer would appear to be no.

Fujiwara (2018) in an editorial for the Asahi Shimbun, critiqued the rapid downward trend of English proficiency in Japan. She noted that Japan now ranked 49th amongst the 88 non-speaking countries and regions in the world. A closer look at the English Proficiency Index (Abb. EPI), which categorizes English ability based on the test results from 2.2 million people spread across 100 non-native English-speaking countries, places Japan in the lowest proficiency category. What is most striking is that the proficiency from 2011, where Japan ranked 14th out of 100 countries, and was considered 'moderate' in its proficiency, has declined substantially over 10 years, causing Japan to be ranked 55th out of 100 countries (Fujiwara, 2018). The Jet Programme, whose participants are spread across 45 prefectures, have increased their presence in the classroom exponentially since 2011, with a current participant total of more than 5,761 instructors in Japan (Jet Programme history, 2019). Japan's Ministry of Affairs and Internal Communications, the Ministry of Foreign Affairs, and the 
Ministry of Education came to a consensus in terms main goals for the JET program; "to help improve foreign language education"(MIC, 2020). However, the proof of Japan's declining English proficiency, as provided by the EPI, is a direct contradiction to the government's ambitions for JET.

In fact, according to the Education Ministry National Institute for Educational Research, 2019 nationwide test results also highlighted Japanese students' poor English-speaking ability. The rankings were taken across 29,518 schools, and ranked students' English ability on a yearly aptitude test. Out of a score of $100 \%$, students received an average of $68.3 \%$ for listening, 56.2\% for speaking, $46.4 \%$ for writing, and $30.8 \%$ for speaking (Osumi, 2019, p.1). While the anticipated outcome of having native speakers in the classroom, often used as justification for the continuation of the JET Programme, would be an improvement in the communication ability of students, the statistical data confirmed by national test results do not support this narrative. These figures provided are based on all national and municipal schools across Japan, and half of the country's private schools.

In terms of cultural exchange, the JET Programme has provided opportunities for Japanese citizens to interact with foreigners in person, that potentially they may not have had. While the programme has grown in numbers, foreign residents have also grown to an all-time high in Japan. Up from 1.8 million in 2014, to almost 2.49 million in 2019, the number of foreigners living in Japan has been exponential. However, despite this change in the population dynamic, researcher Maiko Eiraku (2019) reports that interest in interacting with foreigners is down almost an average total of $75 \%$ across the survey questions. Two polls were conducted by the NHK broadcasting culture research institute; one in 1993 and one in 2018. The participants included roughly 3,000 Japanese people above the age of 16. The data shows a drastic drop in interest towards foreign countries, the ratio of foreign friends, the interest in going abroad, and the amount of contact that they have with foreign people in their daily lives. Eiraku (2019) concludes that Japan may be experiencing a changing view of foreigners in Japan.

While we have a looked at a variety of perspectives, surveys, and previously conducted studies regarding the JET Programme, one crucial voice has perhaps been overlooked; the voice of the Japanese teacher. In a comparative study conducted amongst teacher preparation and qualifications amongst six nations, it was found that Japan had one of the most competitive teaching industries. In fact, only $30 \%$ of graduates from teacher training colleges are able to secure employment in public schools after graduation. Japanese teachers are subjected to a battery of tests decided by the prefectural board of education. These tests can range from written tests, proficiency tests, pedagogical theory and methods, educational psychology tests, student guidance, education laws and regulation review, school culture, and school management exams (Fujita, 2007, as cited in Ingersoll, 2007, pp. 41-43). Fujita (2007) explains that the training process for Japanese teachers is "multidimensional, continuous, and systematic"(as cited in Ingersoll, 2007, p. 43). 


\section{Quantitative Research from the trained Japanese Teacher's Perspective}

\section{Participants}

The participants for this concentrated study were chosen as a result of their direct proximity to assistant foreign language instructors in their daily lives. The participants consist of 65 trained, licensed, and experienced full-time Japanese English teachers. The teachers were selected from Junior high schools and high schools from two regions in Japan; Shikoku in southwest of Japan's main island Honshu, and the Chugoku region of Japan, containing Hiroshima, Okayama, Shimane, Tottori, and Yamaguchi prefectures.

The participating teachers from different schools from all regions were comprised of teachers with a wide range of teaching experience. On the questionnaire I asked all participants to list their years of teaching experience. With this information, I grouped fall of the combined English departments into four categories of teaching experience; 0-3 years' experience, 4-7 years' experience, 8-14 years' experience, and more than 15 years teaching experience. Two independent variables; group 1 defined as inexperienced teachers, and group 2 defined as experienced teachers, will comprised by combining 0-3 years' experience and 4-7 years' experience teachers, and 8-14 years' experience and more than 15 years' experience into comparable groups. The 65 teachers were presented with a 10-question ordinal scaled Likert survey. The range was determined by taking the lowest number of the scale, subtracting that from the highest number, and dividing it by the highest number again $(5-1=4,4 / 5=0.8)$. The least value in the scale was then added to identify the maximum range. The range of the scale are as such: 1.00-1.80 will represent "strongly agree", 1.81-2.60 will represent "agree", 2.61-3.40 will represent "undecided", 3.41-4.20 "disagree", and will represent and 4.21-5.00 will represent "strongly disagree". Q1-Q10 were selected for cross-analysis. I used this range system to classify the results with more accuracy using the SPSS statistics software as a calculation instrument.

Table 1: 10 Question Likert Scale

$\begin{array}{|ll|}\text { Q1 } & \begin{array}{l}\text { Do you think that foreign instructors in Japan should have a background in education? } \\ \text { Q2 }\end{array} \\ \text { I think teaching is as important as other vocations in society such as; lawyers, doctors, police } \\ \text { officers, dentist, accountants, etc. }\end{array}$




\section{Internal Consistency of Likert Scale}

Initially, before analyzing the results of the ordinal Likert scale, the internal consistency of the presented questionnaire was checked for reliability. Using Cronbach's Alpha, assuming measurement for consistency from .00, representing no consistency in measurement, to 1.0, representing perfect consistency, the alpha coefficient of the 10 scales was found to be $\alpha=.89$. According to Cronbach's Alpha, this variance result was $0.9>\alpha \geq 0.8$, indicating satisfactory evidence of reliability within the 10 items collectively in assessing the opinions of each participant.

\section{Null and Alternative Hypothesis}

Null hypothesis $\left(\mathrm{H}_{0}\right)$ and the alternative hypothesis $\left(\mathrm{H}_{1}\right)$ are as follows: The null hypothesis, represented by $\mathrm{H}_{0}: \mu=(2.61-3.40)$ states that there is no significant difference in the opinions regarding the importance of teacher training in foreign instructors with respect to a Japanese teacher's experience in the teaching field. In other words, regardless of years of experience, a Japanese teacher would be ambivalent to whether or not a foreign instructor in the Japanese classroom had sufficient training or a background in education.

The alternative hypothesis, represented by $\mathrm{H}_{1:} \mu \leq 2.60 \mu \neq(2.61-3.40)$, proposes the younger, or less experienced Japanese teachers are more tolerant and less inclined to believe that foreign instructors need formal training or an education background. Conversely, more experienced Japanese teachers believe that training should be a requirement. There is a definitive difference in opinion towards foreign instructors based on years of experience.

\section{Result Mean Comparison between Inexperienced and Experienced Japanese teachers}

Table 2 : Group 1 mean data

\begin{tabular}{|c|c|c|c|c|c|c|c|c|c|c|c|}
\hline \multirow{2}{*}{$\begin{array}{l}\text { Inexperienced } \\
\text { Japanese teacher }\end{array}$} & \multirow{2}{*}{$\mathrm{N}$} & \multicolumn{10}{|c|}{$\begin{array}{l}\text { Sample Mean } \\
\text { Std. Deviation }\end{array}$} \\
\hline & & Q1 & Q2 & Q3 & Q4 & Q5 & Q6 & Q7 & Q8 & Q9 & Q10 \\
\hline $\begin{array}{l}\text { 0-3 years' } \\
\text { experience }\end{array}$ & 16 & $\begin{array}{l}4.2 \\
.62\end{array}$ & $\begin{array}{l}1.9 \\
.62\end{array}$ & $\begin{array}{l}3.00 \\
.00\end{array}$ & $\begin{array}{l}2.94 \\
.44\end{array}$ & $\begin{array}{l}3.19 \\
.66\end{array}$ & $\begin{array}{l}4.10 \\
.70\end{array}$ & $\begin{array}{l}3.56 \\
.73\end{array}$ & $\begin{array}{l}3.44 \\
.51\end{array}$ & $\begin{array}{l}3.20 \\
.52\end{array}$ & $\begin{array}{l}2.50 \\
.73\end{array}$ \\
\hline $\begin{array}{l}\text { 4-8 years' } \\
\text { experience }\end{array}$ & 19 & $\begin{array}{l}2.9 \\
.65\end{array}$ & $\begin{array}{l}1.8 \\
.42\end{array}$ & $\begin{array}{l}3.21 \\
.42\end{array}$ & $\begin{array}{l}2.74 \\
.56\end{array}$ & $\begin{array}{l}2.05 \\
.40\end{array}$ & $\begin{array}{l}2.78 \\
.61\end{array}$ & $\begin{array}{l}3.68 \\
.87\end{array}$ & $\begin{array}{l}3.68 \\
.67\end{array}$ & $\begin{array}{l}3.67 \\
.61\end{array}$ & $\begin{array}{l}3.05 \\
.40\end{array}$ \\
\hline Average mean* & 35 & 3.55 & 1.85 & 3.10 & 2.84 & 2.62 & 3.44 & 3.62 & 3.56 & 3.43 & 2.77 \\
\hline
\end{tabular}

Note: $\mathrm{N}=$ number of participant

*The total average of means between teachers with 0-3 years' experience and teachers with 4-8 years' experience will be defined as group 1, inexperienced Japanese teachers. 
Table 3: Group 2 mean data

\begin{tabular}{|c|c|c|c|c|c|c|c|c|c|c|c|}
\hline \multirow{2}{*}{$\begin{array}{l}\text { Experienced } \\
\text { Japanese teacher }\end{array}$} & \multirow{2}{*}{$\mathrm{N}$} & \multicolumn{10}{|c|}{$\begin{array}{l}\text { Sample Mean } \\
\text { Std. Deviation }\end{array}$} \\
\hline & & Q1 & Q2 & Q3 & Q4 & Q5 & Q6 & Q7 & Q8 & Q9 & Q10 \\
\hline $\begin{array}{l}\text { 9-14 years' } \\
\text { experience }\end{array}$ & 16 & $\begin{array}{l}1.9 \\
.50\end{array}$ & $\begin{array}{l}1.9 \\
.50\end{array}$ & $\begin{array}{l}3.44 \\
.51\end{array}$ & $\begin{array}{l}2.15 \\
.72\end{array}$ & $\begin{array}{l}2.00 \\
.00\end{array}$ & $\begin{array}{l}2.13 \\
.62\end{array}$ & $\begin{array}{l}3.31 \\
.60\end{array}$ & $\begin{array}{l}3.48 \\
.62\end{array}$ & $\begin{array}{l}1.64 \\
.57\end{array}$ & $\begin{array}{l}1.69 \\
.79\end{array}$ \\
\hline $\begin{array}{l}15+\text { years' } \\
\text { experience }\end{array}$ & 14 & $\begin{array}{l}1.4 \\
.51\end{array}$ & $\begin{array}{l}1.8 \\
.43\end{array}$ & $\begin{array}{l}3.29 \\
.61\end{array}$ & $\begin{array}{l}2.50 \\
1.02\end{array}$ & $\begin{array}{l}1.15 \\
.47\end{array}$ & $\begin{array}{l}2.14 \\
.53\end{array}$ & $\begin{array}{l}3.50 \\
.76\end{array}$ & $\begin{array}{l}3.57 \\
.65\end{array}$ & $\begin{array}{l}1.43 \\
.27\end{array}$ & $\begin{array}{l}1.36 \\
.50\end{array}$ \\
\hline Average mean* & 30 & 1.65 & 1.85 & 3.36 & 2.32 & 1.57 & 2.13 & 3.40 & 3.25 & 1.53 & 1.52 \\
\hline
\end{tabular}

\section{Mean Comparisons between Questions}

*Question 1, concerning education background, data shows that Group 1 remained "disagree" on the topic within the Likert scale range of 3.41-4.20, while Group 2 fell within the Likert scale range of 1.00-1.80, asserting that they "strongly agree" with this question.

Questions 2 and 3 both resulted in similar opinions. Both inexperienced and experienced Japanese teachers "agree"(range 1.81-2.60) that teaching is as important as other vocations in society, and remained "undecided" if ALTs from other countries teach high quality English classes to Japanese students.

*Question 4 resulted in inexperienced Japanese teachers being "undecided"(range 2.61-3.40) if only licensed teachers should be allowed to teach at schools, while experienced Japanese "agree"(range 1.81-2.60) that only licensed teachers should be allowed to teach at schools.

*Question 5 resulted in inexperienced Japanese teachers being "undecided" about foreign ALTs or JETs receiving proper training, while experienced Japanese teachers "strongly agree" that foreign ALTs and JETs should receive proper training.

${ }^{*}$ Question 6 resulted in inexperienced Japanese teachers choosing that they "disagree"(range 3.41-4.20) about feeling uncomfortable being taught by an untrained teacher, and experienced Japanese teachers stating that they "agree"(range 1.81-260) that they would feel uncomfortable being taught by an untrained teacher.

Question 7 resulted in experienced Japanese teachers stating that they "disagree"(range 3.41-4.20) with feeling a level of stress when they taught with an untrained teacher. On the other hand, experienced Japanese teachers reported that they were "undecided"(range 2.61-3.40) on this topic. Interestingly, when you look at the standard deviation from the teacher's with 14+ years' experience -while still below the 1 threshold that indicates a low variance, it was .76, suggesting that the data was widely spread. Some of these experienced teachers felt a level of stress, and some felt no stress. 
*Both Questions 8 and 9 yielded substantial differences in opinion. Inexperienced Japanese teachers "disagreed"(range 3.41-4.20) that foreign teachers should have an official English teaching license, and that they "disagree" (3.41-4.20) that ALTs should be required to possess a certification such as TESOL or CELTA. Experienced Japanese teachers were "undecided"(range 2.61-3.40) whether teacher foreign teachers should possess an official English teaching license, and stated that they "strongly agree"(range 1.00-1.80) ALTs should hold a certification in either TESOL or CELTA. The standard deviation in group 2 were .57 and .27 in this particular question, suggesting a degree of reliability in that the data was clustered closely to the mean average.

*Question number 10, which related to whether or not the local boards of education should offer appropriate training for ALTs also differed greatly. Inexperienced Japanese teachers were "undecided" (2.61-3.40) about this training. Experienced Japanese teachers chose that they "strongly agree" $(1.00-$ 1.80) that this training should be provided.

\section{Data Analysis Results}

There were substantial differences between Group 1 and Group 2 in terms of the Likert Scale results. The differences in the questions regarding to necessity for an education background for foreign instructors (Q1), and the need for training and certification for foreign instructors (Q4, Q5, Q6, Q8, Q10) were significantly different between group 1 and group 2 .

The results derived from experienced Japanese teachers (Group 2) would suggest that they either "agree" or "strongly agree" that foreign instructors should receive appropriate training and have a background in education before attempting to teach in a Japanese classroom.

The cumulative average of Group 2's means for their answers to the questions (Q1, Q4, Q5, Q6, Q9, Q10) was 1.53. Therefore, I can reject the null hypothesis $\mathrm{H}_{0}: \mu=(2.61-3.40)$ stating that there is no difference in opinion between inexperienced and experienced Japanese teachers regarding foreign instructors in Japan, and I can accept the alternative hypothesis of $\mathrm{H}_{1}$ : $\mu \leq 2.60 \mu \neq(2.61$ 3.40).

The cumulative average of Group 1's means for the answers to the questions (Q1, Q4, Q5, Q6, Q9, Q10) was 2.66. These results showed that the less experienced Japanese teachers were less concerned with untrained foreign teachers, and less concerned about their credentials or qualifications.

\section{Conclusion}

Recent research suggests that the relationship between experience and teacher competency is a "multidimensional construct, that finds little evidence in beginner teachers being any less competent that veteran experienced teachers (Graham et al., 2020. p.6). However, in the case of Japan, as Kiernen (2020) points out, being a trainer is built into many roles within the Japanese workplace. The 
responsibility on Japanese teachers, both inexperienced and experienced, of training foreign teachers with little to no background in education, may feel like a burden. With years of experience, this burden could be compounded, causing a change in attitude towards working with untrained foreign instructors.

Teacher's play a vital role in our society, and from the strict adherence to training standards for Japanese teachers, it would appear that this sentiment is shared by the Japanese. If this stands to be the case, then there is clear doublestandard for foreign English ALT instructors who are allowed to teach in classrooms throughout Japan without training.

\section{References}

2019 JET Programme Participant Information. (2020). Ministry of Education, Culture, Sports, Science and Technology (MEXT). Tokyo.

Ang, J. (2021). Asian countries with the highest and lowest English proficiency. Human Resources Online.net. https://www.humanresourcesonline.net/asian-countrieswith-the-highest-and-lowest-english-proficiency

Allison in Tokyo. (2020, November, 11). How much do you make on the JET Program? my income, bills taxes, and budget. [Video]. https://www.youtube.com/watch?v=tAjFFNyrMEk

Brown, C. (2008). The JET program's mission accomplished? The English Teacher's Magazine, 57(2), 21-24. https://ndlonline.ndl.go.jp/\#!/detail/R300000002I9464437-00

Borg, P. (2018). What is the JET programme really good for? A discussion of the official discourse and policy. Gifu Kyoritsu University Journal, 52(2). http://gkurepository.gku.ac.jp/bitstream/11207/274/1/ronshu_52\%282\%29_089_borg.pdf

Canales, L. (2015). Whip, Love, and Videotapes-The Myth of Japanese Education. Boston, Mass: Branden Books.

Car adventures. (2017, May, 31). How much do Alts really make? [Video]. YouTube. https://www.youtube.com/watch?v=8zu5Nr8tCd0

Cambridge English Dictionary (n.d.). Certified. In Cambridge English.com dictionary. https:/ / dictionary.cambridge.org

Cambridge English Dictionary (n.d.). Licensed. In Cambridge English.com dictionary. https://dictionary.cambridge.org

Debella, M. (2018). How to get a teaching job in Vietnam. Teach Abroad. Retrieved from https://www.gooverseas.com/blog/get-job-teaching-abroad-Vietnam

Eiraku, M. (2019, January 10). The changing view of foreigners in Japan. NHK Worl Japan News. https://www3.nhk.or.jp/nhkworld/en/news/backstories/336/

EPI English Proficiency Index - Japan (2020). EF Index. https://www.ef.com/wwen/epi/regions/asia/japan/

Fujita, H. (2007). The qualifications of the teaching force in Japan. In A comparative study of teacher preparation and qualifications in six nations. Philadelphia, PA: Graduate School of Education, University of Pennsylvania, pp. 41-54. https://eric.ed.gov/?id=ED498318

Fujiwara, G. (2018). Japan ranked $49^{\text {th }}$ in English proficiency, rated low again. The Asahi Shimbun. http://asahi.com/ajw/articles/AJ201811120058.html

Graham, L., White, L. J., Cologon, K., \& Pianta, R. (2020). Do teachers' years of experience make a difference in the quality of teaching? Teaching and Teacher Education, 96, 1-8. https://doi.org/10.1016/j.tate.2020.103190 
Hatoyama, Y. (2009, September, 16). Basic Policies of the Hatoyama Government [translated speech]. Prime minister of Japan and his cabinet. https://japan.kantei.go.jp/hatoyama/statement/200909/16policies_e.html

Ingersoll, R. M. (2007). A comparative study of teacher preparation and qualifications in six nations. Philadelphia, PA: Graduate School of Education, University of Pennsylvania.

Ishi, S. (2009). JET Program wa haishi subeki. Seisaku Kenkyu Report: Jichitai Sougou Seisaku Kenkyujou [The Jet Program should be abolished. Policy Research Report: Comprehensive Local Municipality Policy] 32, 1-43. http://www.dp17299250.lolipop.jp/userdata/jichi_200912hp.pdf

Jet Programme History (2019). Official Jet Programme Website. http://jetprogramme.org/en/history/

Keirnen, S. M. (2020). The unskilled, semi-skilled, firms \& organizations of training-a few points of view. Fundación Marcelino Munoz. https:// fundacionmarcelinomunoz.org/wpcontent/uploads/2021/03/Articulo-6-Unskilled-Semi-skilled-FirmOrganisation-of-Training.pdf

Kenszei, P. (2018). What are the qualifications to teach abroad in South Korea. Teach Abroad. https://www.gooverseas.com/blog/qualifications-teach-abroad-SouthKorea

Liang, Z. (2019). Teaching English in China requirements. Teach Abroad. https:// pandabuddy.net/teach-in-china-requirements

Maeda. H. (2010). A contextual analysis of the Japan exchange and teaching program (JET). Mejiro University: Humanities Research Journal, 9, 221-228. https://mejiro.repo.nii.ac.jp/?action=repository_uri\&item_id=1067\&nc_session $=\mathrm{d} 686 \mathrm{ttsf5}$ pe1lgddr7q8tfl4k5

Mason, R. H., \& Caiger, J. G. (2001). A History of Japan. Rutland, VT: C.E. Tuttle Co.

McConnell, D. (1996). Education for global integration in Japan: a case study of the JET Programme. Human Organization, 55(4), 446-457. https://www.jstor.org/stable/44127862

McConnel, D. (2000). Importing Diversity: Inside Japan's JET Programme. University of California Press, London, England.

Metraux, D. A. (2001). Under the Gaijin gaze: essays on the education $\mathcal{E}$ attitudes of Japanese college women. San Jose, CA: Writers Club Press.

Metzger, E. (2012). Promoting Japan: One Jet at a time. CPD Perspectives on Public Diplomacy, 2012. http://uscpublicdiplomacy.org/sites/uscpublicdiplomacy.org/files/useruploa ds/u35361/2012\%20Paper\%203.pdf

Ministry of Internal Affairs \& Communication Autonomous Finance Bureau (2005). Kokusaika Suisen Taisaku [International promotion measures] [kokusaika suisen taisaku]. http://www.soumu.go.jp/iken/pdf/c-keikaku-17-5.pdf

Ministry of Internal Affairs \& Communication-MIC (2020). Cross cultural exchange: JET Program explanation. http:/ / www.soumu.go.jp/kokusai/kouryu.html\#a

Morikawa, T. (2019). Native-speakerism or English as a lingua franca?: on the future direction of English as a foreign language education in Japan. Komaba Journal of English Education, 25-25. http://park.itc.u-tokyo.ac.jp/eigo/KJEE/010/025046.pdf

Norimitsu, T. (1997). Linguistic imperialism and teaching English in Japan. The GeibunKenkyu: Journal of Arts and Letters, 73(12), 508-517. https://koara.lib.keio.ac.jp/xoonips/modules/xoonips/detail.php?koara_id=A N00072643-00730001-0508 
Ohtani, C. (2010). Problems in the assistant language teacher system \& English activity in Japanese public. Educational Perspectives, 43(2), 38-45. https://eric.ed.gov/?id=EJ912113

Osumi, M. (2019). Nationwide test results highlight Japanese students' poor English speaking. The Japan Times. https://www.japantimes.co.jp/news/2019/08/01/national/nationwide-testresults-highlight-japanese-students-poor-english-speaking-writing-skills/

Reed, D. R. (2015). Contemporary roles of foreign English teachers in Japanese public secondary schools: an exploratory study. Asian EFL Journal, May 2015. https://asian-efl-journal.com/wp-content/uploads/Nathaniel-David-Reed.pdf

Rivers, D. J. \& Ross, A. S. (2013). Idealized English teachers: the implicit influence of race in Japan. Journal of Language, Identity, and Education, 12, 321-339. https://www.researchgate.net/publication/262872100_Idealized_English_Teac hers_The_Implicit_Influence_of_Race_in_Japan

Sarah loves Japan. (2019, October, 10). What is the JET Program? Is it worth it?. [Video] YouTube. https://www.youtube.com/watch?v=KtNRx7qumWM

Shapiro, N. (1983). Japan: hopes and fears for Nakasone. Harvard International Review, 5(6), 33-36. http://www.jstor.org/stable/42759618

Solmon, L. C. \& Schiff, T. W. (Eds). (2004). Talented teachers: the essential force for improving student achievement. Greenwich, Conn: Information Age Publishing.

Statista. (2021). Number of education institutions in Japan in 2020, by type. Statista. https://www.statista.com/statistics/647533/japan-educational- establishmentnumber-by-type/

Teachers Council of Thailand. (2019). The TCT teaching license/Khurusapha requirements in 2019. http://seetefl.com/tct-teaching-license

Tenma, M. (2008). Dare mo shiranai ALT [What people don't know about ALTs]. http://www.ryugaku-higai.com/alt.html

The Council of Local Authorities for International Relations (CLAIR) (2015). The history of the JET Programme. http://www.jetprogramme.org/en/history/

The end of the JET Program?. (2010, August 23). Gaijinpot. https://injapan.gaijinpot.com/work/teaching-in-japan/2010/08/23/the-endof-the-jet-program/

Yazawa, O. (2017). Students' Perception of Native English-Speaking Teachers and Japanese Teachers English: The Effect on Students' Self-Efficacy and Emotional State. Eruditi, 1, 61-72. http://www.cgcs.c.u-tokyo.ac.jp/eru/vol1/YazawaStudents-Perception_of_Native_English-

Speaking_Teachers_and_Japanese_Teachers_of_English-201706CCL.pdf 